\title{
Ethnic Violence and the Prospects for Democracy in the Aftermath of the 2007 Kenyan Elections
}

\author{
Adam Ashforth
}

On the night of December 29, 2007, Kenya seemed poised for that rarest of achievements in Africa, a peaceful handover of power to an opposition party in a democratic election. The opposition Orange Democratic Movement (ODM) had defeated the Party of National Unity (PNU) of incumbent president Mwai Kibaki in the parliamentary election, winning ninety-nine seats to forty-three. Raila Odinga, the ODM presidential candidate, was leading in the presidential vote count by more than a million votes. The next day, however, the Electoral Commission of Kenya announced that the sitting president had been reelected by a margin of fewer than a quarter million votes. ${ }^{1}$ In a hastily arranged ceremony closed to the public, Kibaki was sworn in for a second term. The country exploded.

Through the months of January and February 2008, some fifteen hundred people were killed and five hundred thousand displaced from their homes in violence fueled by outrage over the stolen election. ${ }^{2}$ As the killing and burning spread across the country in early January, Kofi Annan, the former secretary-general of the United Nations, was called in to mediate between the two rival leaders and their parties. After exhausting negotiations, Annan brokered a deal at the end of February in which the two parties would form a "grand coalition" government

1. The Electoral Commission's Web site lists a page for the 2007 results (www.eck.or.ke/index .php/Election-Results-Database).

2. For a good overview of the events of January and February, see Human Rights Watch, Ballots to Bullets: Organized Political Violence and Kenya's Crisis of Governance, Human Rights Watch series, vol. 20, no. 1 (A), www.hrw.org/reports/2008/kenya0308.

Public Culture 21:1 DOI 10.1215/08992363-2008-018 
of national unity. This cabinet was sworn in on April 17, with President Kibaki remaining as head of state and a new post of executive prime minister being created for Odinga. ${ }^{3}$ On May 14 the new cabinet met for the first time, and Kenya once again had a government. Once again, incidentally, Kenya has no formal parliamentary opposition. At the top of the new government's agenda is the difficult task of repairing the social damage caused by the postelection violence.

Kenyans as well as outside observers were shocked by the rapidity of the country's collapse into chaos in early January 2008. For decades Kenya had seemed the stable exception in a region racked with civil war and ethnic conflict, a haven for refugees from other parts of Africa-Congo, Rwanda, Somalia, Sudan, and Uganda - not a source of strife in its own right. Despite a long history of "ethnic clashes," most Kenyans seemed reasonably comfortable in recognizing one another as both Kenyans and members of different "tribes." Kenyans carry a national identity card listing their affiliation to one of "forty-two tribes," though few can name them all, and occasionally another group voices a demand for tribal recognition. ${ }^{4}$ In the chaos that followed the announcement of the poll results, warnings of "another Rwanda" in the making were commonplace. For while outrage over the stolen election sparked the violence, there were undeniably ethnic aspects to the killing. Yet while there was no Rwanda-style genocide, most of the violent clashes occurred along ethnic lines. The ethnic dimensions, however, were not the same in all instances. ${ }^{5}$

Broadly speaking, five types of ethnic conflict marked the aftermath of the

3. The cabinet was finally sworn in with forty ministers (twenty from each side) and fifty-two assistant ministers, almost half the total number of members of Parliament (MPs). The cost of running such an enormous executive will consume much of the discretionary funds in the Kenyan budget. The Daily Telegraph estimated that "of Kenya's annual budget of $£ 5.4$ billion, more than $£ 4.3$ billion will go on 93 ministers and their government's general running costs. Only $£ 1.3$ billion will be left for roads, schools and hospitals for Kenya's 38 million people" (Mike Pflanz, "Kenya's Cabinet Soaks Up $80 \%$ of Budget," Daily Telegraph, April 18, 2008, www.telegraph.co.uk/news/world news/1895899/Kenya\%27s-cabinet-\%27soaks-up-80pc-of-the-budget\%27.html).

4. For a discussion of the Sengwer and their efforts to gain official recognition, see Gabrielle Lynch, "Negotiating Ethnicity: Identity Politics in Contemporary Kenya," Review of African Political Economy 107 (2006): 49-65.

5. John Lonsdale has famously argued for a distinction between "moral ethnicity" — "a process of "ourselves-ing", — and the "othering" force of "political tribalism" ("Moral and Political Argument in Kenya," in Ethnicity and Democracy in Africa, ed. Bruce Berman, Dickson Eyoh, and Will Kymlicka [Oxford: Currey; Athens: Ohio University Press, 2004], 76). In Lonsdale's view, the former provides communities with resources for resisting the totalizing inclinations of the state. The latter is a weapon most serviceable to the holders of power within the state and to those contending for it. The ethnic conflicts I describe herein could all be considered forms of political tribalism. Little morality can be found in them. 
elections: ethnically targeted state repression; targeting of local ethnic proxies for national political figures; ethnic vigilantism; opportunistic criminal violence (some of which, it should be pointed out, was not ethnically motivated); and ethnic cleansing by Kalenjin ethnonationalists. In this essay I anatomize the postelection violence in Kenya to identify the different forms of ethnic conflict so as to analyze the implications for the future stability of a democratic regime in the country. None of these forms of violence is unique to Kenya. Numerous examples of similar conflicts can be found in many parts of the world, particularly in contexts of emerging democracies following authoritarian rule. Since the Kenyan case of Kalenjin nationalism is relatively unfamiliar in the literature on ethnic nationalism, however, I focus here on the historical specifics of this case.

The first and perhaps most straightforward type of violence marking the postelection period involved police suppression of protests around the country in defense of what had become an ethnically exclusive regime. Virtually everyone killed or injured by a bullet in the weeks after the election was shot by officers of the state. (Favored weapons of nonstate actors included arrows, pangas [machetes], stones, and fire.) Immediately after the election results were made public, the opposition cried foul and announced a program of protest. In response, the newly reinstalled president proclaimed a ban on all political gatherings and ordered the security forces of the police and the paramilitary General Service Unit (GSU) to clamp down on dissent. The GSU is an elite force created by Jomo Kenyatta in a deliberate effort to deter potential coup plotters within the military. ${ }^{6}$ Kenyatta stacked the GSU leadership with Kikuyus; Daniel arap Moi, the second president, appointed members of his tribe, the Kalenjin. Kibaki and his allies no doubt have done something similar to secure the loyalty of this key security force. Numerous reports document police failing to act against members of their own ethnic groups or acting harshly against others. In the worst incident, police in Kisumu killed forty-four people on December 29 as they protested delays in releasing the election results. The chief of police admitted that she had given "shoot to kill" orders. ${ }^{7}$ In January the army was briefly deployed to quell fighting in Naivasha and Nakuru and to secure the road from the coast through to the north of the country and the central African states beyond, but the soldiers were rapidly returned to their barracks.

6. See Boubacar Ndiaye, "How Not to Institutionalize Civilian Control: Kenya's Coup Prevention Strategies, 1964-1997,” Armed Forces and Society 28 (2002): 619-40.

7. See "Kenya Police Commander Says She Ordered Shooting of Protesters," Associated Press, January 16, 2008, www.iht.com/articles/ap/2008/01/16/africa/AF-GEN-Kenya-Open-Fire.php. 
The second type of conflict involved violent protests targeting Kikuyu persons and property as proxy attacks on the president and his party. These clashes were particularly intense in the Luo districts of western Kenya but were also common in Nairobi and the Rift Valley. Local and international observers typically referred to these incidents as "intercommunal violence," a phrase that should be used judiciously, though the fact remains that many of the perpetrators acted with the support of their communities. The logic of these attacks seems to have been the conviction that Kikuyus were valid targets, as they either voted for Kibaki or stood to benefit from his victory, as they had in the past. The Luo people, the story went, had been robbed of their chance, so long postponed, to eat of the state. As the weeks dragged on, it was rare to find Kikuyu leaders or intellectuals speaking out against the fraudulent election, confirming for many the communal basis of the theft. Leaders of virtually every other ethnic group in Kenya were critical of the results. Luos, however, were not the only people involved in such proxy attacks. As one young man told me at the time, echoing a widespread sentiment: "It's all tribes against one."

The third type of conflict arose in response to the targeting of Kikuyus and involved fights among groups of young men organized into ethnic vigilante gangs. These were primarily identified as Luo or Kikuyu. Clashes between such gangs were concentrated in the Nairobi slums, although similar clashes occurred in towns of the Rift Valley, such as Nakuru and Naivasha, between Kikuyu and Kalenjin (as well as Luo and Luhya) youths. These gangs set about segregating residential territories along ethnic lines and defending their turf from outsiders. As the violence spread, rumors abounded about the activities of the Mungiki, a Kikuyu ethnic militia known for its practice of "oathing" in a manner reminiscent of the nationalist fighters of the Mau Mau rebellion. For a time under Moi's regime, the Mungiki were provided with a degree of state support, but in recent years they were outlawed and retreated to running a protection racket in the matatu transport sector and in urban slums. Mungiki were also subjected to a brutal assault by police, who, according to some observers, took advantage of the mandate to eliminate the Mungiki and engaged in a spree of extrajudicial killings targeting people who were not always associated with the organization. In January rumors surfaced, reported by the $\mathrm{BBC}$, that the state was once again collaborating with Mungiki. ${ }^{8}$ Almost certainly, young men associated with the movement

8. See BBC News, "State 'Sanctioned' Kenyan Clashes," March 5, 2008, news.bbc.co.uk/2/hi/ africa/7279149.stm. 
were involved in the fighting. Visiting Naivasha in March with a colleague, I was told by young men about the arrival of Mungiki at the height of the violence and their insistence that all Kikuyu men join them in the battle. As with such rumors in time of war, the reality of a concerted organization by Mungiki was probably less significant than the fantasy suggested. The fantasy alone, however, can be enormously destructive.

The fourth type of conflict in the aftermath of the election involved opportunistic crimes. In the later weeks of February it became clear that ordinary criminals were also taking advantage of the anarchic circumstances and overstretched police and looting Indian traders' stores or the homes and businesses of members of their own and other communities. Reports from the western city of Kisumu suggested that looting was particularly rampant there, with Indian shopkeepers decamping for the safety of Uganda - no small irony considering the history of the Indian community in that country. Women and girls were targets of sexual violence and, when living as ethnic outsiders in refugee camps, were preyed on by men of all ethnic persuasions. The extent of disorder also led to some ambiguity in placing blame for the murders of political figures. For example, two opposition members of Parliament were killed in circumstances that among their allies raised suspicions of security force involvement and allowed the state to claim that criminals had murdered them. ${ }^{9}$

The fifth type of conflict in the crisis of the postelection period, and the most ominous for the future of Kenya, was marked by a resurgent Kalenjin ethnonationalism that motivated a renewed campaign of ethnic cleansing of Kikuyus by Kalenjins in the Rift Valley. This violence caused the highest number of deaths and displacements and now poses the greatest long-term risk to the stability of the state. In the Rift Valley, the stolen election was a pretext to drive Kikuyu "settlers" from areas of the Rift Valley deemed to belong to "the Kalenjin," a struggle that has deep historical roots. White farmers in the colonial era typically imported Kikuyu farmworkers, many of whom in the independence era remained (though many were expelled in the Mau Mau Emergency of the 1950s). In the postindependence era, tens of thousands of landless Kikuyu were resettled on ex-settler properties in the Rift Valley. In 1991, with the dawn of "multiparty democracy," Kalenjin politicians in the Rift Valley orchestrated clashes to secure

9. Five people were arrested on charges of murder and robbery in connection with the theft of a cell phone and KSh20,000 from ODM Embakasi MP Mellitus Were; a traffic officer in Eldoret was arrested for killing ODM MP David Kimutai Too in what the police claimed was a crime of passion. 
the power of then president Moi. ${ }^{10}$ Supporters of the ruling party, the Kenya African National Union (KANU), led by politicians in Moi's inner circle, worried that opposition parties were attracting strong support from the Kikuyu. They organized squads of young men to attack Kikuyu residents in the Rift Valley, particularly around the towns of Eldoret and Molo, to drive out potential opposition voters and intimidate those who remained. Their strategy, by all accounts supported by the president himself, was successful. Moi won himself ten more years as president by means of "clashes" such as these (though he also bribed voters and officials, repressed dissenters, and rigged his way through elections). At each election since 1992 - 1997, 2002, and 2007 — ethnic clashes have occurred in the Rift Valley. ${ }^{11}$ In each instance the primary perpetrators were people calling themselves "Kalenjin," and the principal victims were Kikuyu, although many innocent Kalenjin were also targets of retaliatory killings.

Yet while there is a surface similarity to the recurring ethnic conflicts surrounding elections in the Rift Valley, the 2008 conflicts differed from earlier clashes in crucial respects. Unlike previous episodes of ethnic violence in the Rift Valley, the mobilization of fighters in 2008 was not organized solely by political leaders seeking to manipulate the ethnic logic of electoral politics to retain power. Rather, the emerging Kalenjin political leadership, while perhaps instigating some violent clashes, took advantage of the widespread attacks on Kikuyus in the region, which arose more or less spontaneously with mostly local and uncoordinated mobilization, and the resulting retaliations against Kalenjin to secure their positions as spokespersons for the Kalenjin. ${ }^{12}$ The 2007 election marks a

10. For an exhaustive account of the advent of multipartyism and an analysis of the Kenyan state under Kenyatta and Moi, see David Throup and Charles Hornsby, Multi-party Politics in Kenya: The Kenyatta and Moi States and the Triumph of the System in the 1992 Election (Oxford: Currey, 1998).

11. For accounts of earlier conflicts, see Jacqueline Klopp, "Can Moral Ethnicity Trump Political Tribalism? The Struggle for Land and Nation in Kenya," African Studies 61 (2002): 269-94; Klopp,

“'Ethnic Clashes' and Winning Elections: The Case of Kenya's Electoral Despotism," Canadian Journal of African Studies 35 (2001): 473-517; and Gabrielle Lynch, "Kenyan Politics and the Ethnic Factor: The Case of the Kalenjin” (DPhil thesis, Oxford University, May 2007).

12. Debate over the degree of organization involved in the Rift Valley battles is unlikely to be resolved. The degree of grassroots Kalenjin support for the expulsion of Kikuyu is evident in that, despite a new policy to support and protect returnees, few displaced families have been permitted by their former neighbors to return home. In March 2008, during interviews in the Nakuru district, I heard some accounts of preparation for violence suggesting that circumcision schools for Kalenjin boys had been held early to prepare them for the election period. That is, moving up the date of the circumcision rituals meant that the boys would not be in seclusion at the time of the election and could be organized into a militia force during their circumcision training. 
changing of the guard in Kalenjin leadersip. Electors comprehensively repudiated former president Moi and his family. Moi had been the central figure in Kalenjin life for more than a half century. Indeed, the very existence of "the Kalenjin" as a plausible ethnic category may owe more to Moi than to anyone else. ${ }^{13}$ Shortly before the election, Moi came out in support of Kibaki. The general response among Kalenjin voters, however, was derision. Many people assumed Moi had made a deal with Kibaki to secure immunity for himself in corruption cases that the opposition might be expected to prosecute if they gained office.

In 2007, for the first time since Moi gained the vice presidency after independence, the Kalenjin as a community entered the elections feeling excluded from the inner sanctums of the state. For some years prior to the elections, Kalenjin nationalism was marked by a collective ressentiment directed primarily at Kikuyu but expressed in frustration at Moi. During his years in office Moi perfected the practice of patrimonial ethnic politics initiated by his predecessor, Jomo Kenyatta. ${ }^{14}$ When Moi was forced from office in 2002, however, and his chosen successor, Uhuru Kenyatta, was defeated in the polls, his former supporters began not only to resent being excluded from the main sources of patronage opportunities but also to critically reassess the spoils that they had received when "Uncle Dan" was in office. A consensus emerged that Moi had dispensed favors primarily to a select group of cronies, while benefiting to an unfair degree the Tugen "subtribe" of the Kalenjin at the expense of other groups, particularly the larger Nandi group. He was also seen to have continued aiding Kikuyus at Kalenjin expense.

Rather than follow the instructions of their former leader and deliver their votes to Kibaki, Kalenjin districts voted overwhelmingly for the opposition. Two of Moi's sons were also humiliated in their election attempts. In the postelection violence, locals took the opportunity to burn some of Moi's properties and those of their impoverished Kikuyu neighbors. The most notable Kalenjin leader is now William Ruto, allied to ODM leader Odinga. Although he is seen in some quarters as a violence-inciting warlord, Ruto claims the mantle of Kalenjin leadership because he delivered their votes for the ODM. As the Kalenjin lawyer and columnist Donald Kipkorir pronounced in April 2008: "In unanimity, Kalenjins have

13. For the most comprehensive account of the making of the Kalenjin and Moi's place in that history, see Lynch, "Ethnic Factor."

14. Kenyatta parlayed state power into political and financial advantage for his relatives and the Kikuyu economic elite, while opening preferential access to land, jobs, and business opportunities for Kikuyus more generally, among whom could be found both the earliest beneficiaries and the fiercest opponents of colonial rule. For a discussion of the differences between Kenyatta's rule and Moi's, see Throup and Hornsby, Multi-party Politics in Kenya. 
chosen Mr Ruto their leader, and on their behalf will he sit at the nation-state table to represent their interests." 15 In the negotiations leading to the "grand coalition" government, Ruto was backed by the implicit threat that his community, if left dissatisfied, would resume its violent struggles.

In March 2008 I traveled to the Rift Valley district of Nakuru with a colleague to visit my in-laws and to report on the aftermath of the violence. ${ }^{16}$ On the way to Nakuru we stopped outside Gilgil at the farm of J. M. Kariuki, the socialist politician assassinated in 1975 after falling out with President Kenyatta. Thirty Kalenjin families, who had lived on the property for generations, since before Kariuki bought it from a white farmer at independence, had been burned out and chased away by Kikuyus in revenge for attacks on Kikuyus farther north. The houses had been small structures of mud and thatch. Nothing remained but scorched ground. The locals we met expressed sorrow at the plight of their neighbors and insisted that the perpetrators came from far away. Later that day we toured farms in the Rongai district outside Nakuru where Kikuyu homes had been burned. Some mud walls remained standing; everything that could be stolen or burned was gone. Thousands of Kikuyu had also been displaced from their homes in the surrounding countryside and were living in refugee camps in the Nakuru Agricultural Showgrounds and the stadium.

None of the Kalenjins we spoke with in the Rift Valley evinced any sympathy for his or her missing neighbors. During my previous visit, in the northern summer of 2007, relations between the two groups in the district had not seemed particularly troubled. Indeed, my Kalenjin in-laws were not alone in having close friends, lovers, and co-parents from the Kikuyu community. On my visit in March, however, I found the ruined houses of people I had thought of as family friends along with those of many other neighbors. The consensus after the 2007 election was that Kikuyu did not belong in this part of the world. "This is Kalenjin territory," was a steady refrain. One woman insisted to us that the Kikuyu actually belonged in Congo, whence they had been imported by white farmers in the days of colonialism.

Central to the question of ethnic identity in Kenya is the politics of land. Six decades of British rule, of identifying peoples with territories in sharper distinc-

15. Donald Kipkorir, "Casting the First Stone," April 6, 2008, kenyaimagine.blogspot .com/2008/04/casting-first-stone.html.

16. My thanks to Robert Blunt of the Department of Anthropology at the University of Chicago for sharing on this trip his extraordinary knowledge of Kenyan history, culture, and politics. 
tions than had been known before and of exploiting cultural difference in the service of ruling through the offices of local "tribal" authorities, laid the foundation for postindependence subnational collective identities. ${ }^{17}$ At the same time, however, the British undermined the potential for establishing exclusive ethnic homelands, such as those in South Africa, by facilitating the creation of private property, with individual tenure, of communal land and opening vast tracts in the Highlands to capitalist commercial agriculture, making the ownership of land the keystone of the economy. In the postindependence era, this property regime remained largely intact, albeit with the substitution of African landholders for white settlers. The families of independent Kenya's three presidents, curiously enough, are the largest landholders in the country. The Kenyattas own more than five hundred thousand acres of agricultural land. Most of the rest of the arable land, which comprises about a fifth of the country, is held by cronies of presidents, while 80 percent of the country either is landless or occupies land sufficient only for residential and bare subsistence purposes. ${ }^{18}$

Decades of illegal and irregular land transactions, coupled with a chronically dysfunctional cadastral bureaucracy, have corrupted Kenya's whole system of landholding. ${ }^{19}$ The ninety-nine-year leases issued by the colonial authorities have now expired, casting doubt on the security of tenure and the viability of mortgages of a huge number of properties, from family subsistence farms in the Rift Valley to multinational corporate plantations and swathes of downtown Nairobi. ${ }^{20}$ Despite a constant refrain to "recognize the sanctity of title," most recently echoed by President Kibaki after the minister of lands announced the revocation of all colonial-era leases, virtually no one can say for certain whether the title to

17. The mapping of each tribe to its territory was formalized in the Carter Commission's boundarysetting work of 1933. See Report of the Kenya Land Commission, September 1933 [Carter Commission Report] (London: HMSO, 1934).

18. For a description of their enormous holdings, derived from "close to a year of interviews with farm staff, independent surveyors, Ministry of Lands experts and land rights NGOs," since public records are not available, see Otsieno Namwaya, "Who Owns Kenya?" Standard, October 1, 2004.

19. See Report of the Commission of Inquiry into the Illegal/Irregular Allocation of Public Land [Ndungu Commission Report] (Nairobi: Government Printer, 2004).

20. Shortly after being appointed minister of lands, James Orengo announced that these leases, most issued prior to 1909 , had lapsed and that the land would revert to the state. This caused panic among landholders and financiers until the president announced, off the cuff at an independence day rally, that the leases could be renewed. The situation, however, remains unclear. See Peter Opiyo, "Warning over Idle Land," Standard, May 22, 2008; Alex Ndewa, "Daggers Are Drawn over Policy on Land," Standard, May 26, 2008; and Kenneth Ogosia, "Kibaki Relaxes Orengo's Tough Land Rules," Daily Nation, June 2, 2008. 
the land he or she occupies is valid. ${ }^{21}$ Thousands of acres of land formerly held in communal tenure under trust have been illegally expropriated by politically connected individuals. ${ }^{22}$ Millions of people, as the recent violence demonstrates, feel passionately about their connection to ethnically defined territory but hold no economically viable property in land. A draft national land policy has been tabled in an effort to begin sorting out the mess that is the land issue in Kenya. ${ }^{23}$ There is a reasonable chance that the policy will be legislated in the near future, though some aspects will require constitutional reform. Implementing such a policy, however, will be a Sisyphean labor.

Insofar as the conflicts of January and February 2008 involved aggrieved supporters of Odinga's ODM, Luos, and others battling police or targeting Kikuyus as supporters of President Kibaki, the prospects for reconciliation are reasonably good. By accepting the post of prime minister in the grand coalition government, Odinga signaled that, whatever benefits the country as a whole might possibly gain in terms of improved governance or new policies, his supporters and his "community" would be rewarded with a seat at the table when the national cake was divided up. His political future will depend to a great extent on how successful he is in convincing these supporters that he has served them well as Luos while cutting whatever deals are necessary with the Kikuyu and other "tribes."

As for the conflicts that involved ethnic cleansing in the Rift Valley, however, the prospects for reconciliation are slim, and the implications for the future of the country are grim. The refugee camps established during the fighting, housing some three hundred thousand people, are now being dismantled, forcing refugees either to return home or to seek shelter elsewhere. Few are returning to the contested zones of the Rift Valley.

In some districts of the Rift Valley virtually no Kikuyu residents are left. The ethnic cleansing of Kikuyus from Kalenjin territory is seen almost without exception, by Kalenjin, as a good thing. In conversations with Kalenjin in the Nakuru district in March 2008, I met only one person who expressed discontent with the course of events, and she was a local politician in the town of Mogotio who had

21. More than two hundred thousand illegal titles were estimated to exist (Ndungu Commission Report, 57). Hundreds of thousands of landholders in the settlement schemes are still awaiting titles to land decades after taking occupation.

22. Ndungu Commission Report, 139.

23. Kenya Land Alliance and Ministry of Lands, Draft National Land Policy (Nairobi: National Land Policy Secretariat, n.d.). 
been forced into hiding because of her unpopular views. Even those not actively engaged in perpetrating or supporting the violence have little sympathy for the people whose relatives were killed and whose houses were burned and properties ransacked. The displaced will not be welcomed home. Moreover, since the leadership of the state has little local influence, attempts to forcibly resettle displaced people are highly unlikely to succeed.

As with those who fled their homes during previous ethnic clashes in the Rift Valley, most will probably end up landless tenants in their ethnic heartlands or among the unemployed in slums and shantytowns in the capital and regional cities. Most of the displaced were involved in subsistence food production. From what my colleague and I saw, none of the plots abandoned by Kikuyu farmers was being prepared for the planting season. Aid organizations are warning of impending food shortages. ${ }^{24}$ Since the land claimed as Kalenjin territory includes large portions of the country's viable commercial agricultural land (with most of the rest in the Central Province, to which the displaced Kikuyus were told to decamp), it is hard to imagine that the recent violence has improved the potential for stimulating much-needed investment in agricultural production. A hardening of attitudes to ethnic territoriality bodes ill also for efforts to redistribute land and address problems of landlessness.

Unlike the eruption of talk of majimboism in 1991, when Kalenjin leaders deployed the rhetoric of regionalism as a weapon against "political pluralism" and multiparty democracy to maintain their power in the state, recent calls for majimbo seem to me more a grassroots popular sentiment fueled by resentment than a coherent political strategy for securing political power at the level of the national state. ${ }^{25}$ No one has yet articulated a viable plan for a regional political entity representing the ethnic homeland. In the ethnic arithmetic that constitutes the Kenyan electoral system, the Kalenjin, like other smaller "tribes," are not well positioned to enjoy the fruits of state power. The destructive potential of their ethnonationalism, as seen in the recent violence, is enormous.

24. In April 2008 the United Nations's Office for the Coordination of Humanitarian Affairs launched an appeal for $\$ 189$ million in relief for Kenya. UN News Centre, "Kenya Facing Food Shortage Because of Rising Prices - UN Aid Officials," April 18, 2008, www.un.org/apps/news/ story.asp?NewsID $=26388 \& \mathrm{Cr}=$ food $\& \mathrm{Cr} 1=$.

25. See Klopp, "Ethnic Clashes." 
